\title{
EXPLORING THE ALLELOPATHIC AND HERMETIC EFFECT OF KHATAMI (Altheae officinalis) ON EMERGENCE AND SEEDLING GROWTH OF RADISH (Raphanus sativus)
}

Rizwan Maqbool ${ }^{1}$, Bilal Ahmad Khan*2, Sumbal Parvez ${ }^{3}$, Muhammad Ather Nadeem², Azhar Hassan', Jamshaid Qamar², Ali Nawaz', Muhammad Adnan², Rafia Khalid ${ }^{3}$, Muhammad Usman $^{2}$

\begin{abstract}
Plant release biochemicals into its surrounding environment that act as bioherbicide at high concentration and plant growth promoter at low concentration. Therefore, this study was planned at the Weed Science laboratory, Department of Agronomy, University of Agriculture Faisalabad-Pakistan, during winter 2018 to evaluate the hermetic effects of Althaea officinalis L. (Khatami) on Radish (Raphanus sativus). The experiments were laid out under completely randomized design (CRD) having three replications. The aqueous extracts of $A$. officinalis $\mathrm{L}$. were used on radish at different concentrations $(2.5 \%, 5 \%, 10 \%$, $20 \%, 40 \%$ and $80 \%$ ). Data regarding seed germination and seedling growth (shoot length, root length, shoot fresh weight, root dry weigh) of radish were recorded using standard procedures. Results revealed that the aqueous extract of $A$. officinalis at higher concentration ( $80 \%$ ) act as bioherbicide and produced inhibitory effects on $R$. sativus that resulted in maximum time to $50 \%$ germination (4.68 days) and mean germination time (9.05 days) while minimum germination index (3.60), germination percentage $(85.00 \%)$, shoot length $(42.4 \mathrm{~cm})$, root length $(25.90 \mathrm{~cm})$, shoot fresh weight $(53.30 \mathrm{~g})$ and root fresh weight $(13.30 \mathrm{~g})$. While at lower concentration $(10 \%)$ it showed hermetic effect and produced maximum germination percentage $(100.00 \%)$, shoot length $(58.2 \mathrm{~cm})$, root length $(52.0 \mathrm{~cm})$, shoot fresh weight $(90.00 \mathrm{~g})$, root fresh weight $(26.30 \mathrm{~g})$ minimum time to complete $50 \%$ germination (3.36 days), germination index $(6.00 \%$ ) and mean germination time ( 5.73 days) growth. In $A$. officinalis among different phenolic compound minimum Syringic acid $(0.60 \%)$ and maximum Quercetion $(12.3 \%)$ compound was found. Therefore, it was concluded from this study that aqueous extract of officinalis can be used as a growth promoter at lower concentration while as well as at higher concentration for environmentally friendly control of weeds.
\end{abstract}

Keywords: Allelopathy, Germination, Growth promoter, Raphanus sativus and Seedling growth.

Citation: Maqbool, R.; B.A. Khan, S. Parvez; M. A. Nadeem; A. Hassan; J. Qamar; A. Nawaz; M. Adnan; R. khalid; M. Usman. 2021. Exploring the Allelopathic And Hermetic Effect Of Khatami (Altheae Officinalis) On Emergence And Seedling Growth Of Radish (Raphanus Sativus). Pak. J. Weed Sci. Res., 27 (3):321-330.

\footnotetext{
${ }^{1}$ Department of Agronomy, University of Agriculture, Faisalabad-3800, Pakistan.

${ }^{2}$ Department of Agronomy, College of Agriculture, University of Sargodha-40100, Pakistan.

${ }^{3}$ Department of Botany, University of Agriculture, Faisalabad-3800, Pakistan.

*Corresponding author: Bilal Ahmad Khan (bilalahmadkhan678@gmail.com)
} 


\section{Introduction}

All crop plant release chemicals into surrounding environment that have the ability to either suppress or promote the growth of the target crop plant or weed. This phenomenon is very important biological control of weeds by releasing secondary metallic compounds. These secondary metabolic compounds are: Tannins, alkaloids, glycosides, cyanogen, sesquiterpenes, phenolic acids, flavonoids, and many others having allelopathic activity (King and Ambika, 2002). Weeds are undesirable plants in main crop that pose aggressive, competitive, troublesome, and multifaceted effect on crops and reduce the yield (Sodaeizadeh et al., 2010). Herbicides are chemicals compounds that are used for managing weeds, but herbicide cause several environmental risks. (Hazrati et al., 2017).

The biochemical compounds manufactured in plant as secondary compounds have a passive role in plants but act as a defense agent in plant. Phenolic as well as terpenoids usually characterized as allelochemical display chemical diversity and number of metabolic and physiological biochemical process. The phenomena of allelopathy in crop plant may increase the yield as well as growth of allelopathic plant via suppressing the weed growth, with the usage of allelochemicals as natural herbicides as well as growth promoter (Einhellig and souza, 1992). These allelochemical can pass into the atmosphere via diverse ways such as leakage, volatilization, root exudations, seed coat exudations by decaying of diverse part of plant (Putnam, 1974; Rice et al., 2007).

Allelochemicals formed in plant might be escaped out from the tissue of plant and different part of plant into soil atmosphere and into the environment through leaching exudation of root, decaying of plant remains and volatilization and effect the growth of neighboring plant (Golisz et al., 2007).

Under stressful condition the concentration of allelochemical in plants increases and under normal conduction the concentration of allelopathic substance remain stable. The main purposes of allelochemical in plants to protect the plant form unpredictable environmental stress such as drought, mineral deficiency, temperature, herbivores grazing, water deficiency, etc. So, stress simply referred as any shortage or excess supply of plant essential compounds that hinder to complete the life cycle and retard the usual growth and development of plant. The aqueous extract of different part of allelopathic plant such as roots, stem, leaves and seed have been used valuable possessions to manage the weed through natural ways (Cheema et al., 2000 a and b; Iqbal and Cheema, 2008; Jamil et al., 2009). Ethanolic or methanolic aqueous extracts were used as possible herbicide in mixtures (Cheema et al., 2012).

By these methods allelochemicals may be able to manage weeds via weaken weed-plant competition and enhance the crop growth and yield (Murrell et al., 2011). Water extract application of allelopathy at lower concentrations stimulate development and growth of diverse crops (Anwar et al., 2003; Cheema et al., 2012: Nadeem et al., 2020a: Nadeem et al., 2020b). Cinnamomum verum are a normal-sized tree (10 to $15 \mathrm{~m}$ ) native to Sri Lanka and tropical- Asia. The tree was cultivated in the Southern India due to strong scented leaf; bark and the aromatic oils take out from him through steam purification. Barks of Cinnamomum verum used in experiment to check the allelopathic potential, plane, light brown color and up to $10 \mathrm{~mm}$ thickness. The foremost compound gain from the bark of $C$. verum is Eugenol, Cinnamaldehyde, phenolic compounds such as chlorogenic acid, vanillic acid, caffeic acid and Linalool (Kubeczka, 2002). The presence of phenolic in bark exhibit inhibitor possession on the plant germination. Althaea officinalis. (Malvaceae), commonly known as khatami are a persistent herb, disseminated in the Himalayas from Kashmir to Himachal Pardesh (National Institute of Science Communication and 
Information Resources, 2003). The seeds of these plants are smooth, diuretic and febrifugal (Mhaskar et al., 2000).

The biochemical investigation of methanolic extract of Althaea officinalis L. showing the presence of phytochemical compound such as glycosides, proteins and amino-acid, and numerous secondary metabolic compounds like phenolic compound such as gallic acid, P-coumaric acid, ferulic acid, saponin substance, tannin elements, flavonoids, oils, resin and mucilage compound. De Feo et al. (2003) examine the allelopathic consequence of $A$. altissima liquid extracts on sprouting and successive root growth of radish (Raphanus sativus L.) and garden cress (Lepidium sativum) that have raised on petri plates comprising filter paper and saturated by liquid abstract of $A$. altissima. A. altissima (Haven tree) abstract repressed the radical development of Raphanus sativus (radish), and garden cress. The vigorous elements were separated from the abstract of $A$. altissima are recognized as phenol and terpenoids (De Feo et al., 2003). De Feo et al. (2003) studies proposed that these compound act as natural herbicides. Therefore, the proposed research was conducted to study the allelopathic effect of Althaea officinalis on vegetable crop (Raphanus sativus).

\section{Materials and Methods Collection of $A$. officinalis plant parts} To make aqueous extract $A$. officinalis (seed) plant parts were purchased from Ayub Agricultural Research Institute of Faisalabad (AARI) Pakistan.

\section{Preparation of $A$. officinalis plant parts aqueous extracts}

Plant parts such as of seed of $A$. officinalis were soaked in distilled water at 1:80 ratio for 2 days (about 48 hours). The aqueous extracts of chopped samples were filter through watman filter paper. The concentrated solution was then diluted with distilled water $(\mathrm{v} / \mathrm{v} \%)$ to make different solutions. Almost seven concentrations (0\%,2.5\%,5\%,10\%,20\%,40\%and $80 \%$ ) were prepared to check the allelopathic activity of the extract. Seven concentrations $0,2.5,5,10,20,40$, and $80 \%$ were prepared by taking extract into $250 \mathrm{ml}$ flask and adding 2.5, 5, 10, 20, 40 and $80 \mathrm{ml}$ stock solution of $A$. officianlis. Whereas controlled solution contained only $250 \mathrm{ml}$ distilled water.

\section{Laboratory Experiment}

Each dilution of each extract was placed in separate bottles and tagged with the respective plant name. The experiment was conducted in $9 \mathrm{~cm}$ petri plate lined with watman filter no.10-filter paper.

To estimate the allelopathic effect $0 \%, 0.25 \%, 0.5 \%, 1 \%, 2 \%, 4 \%$ and $8 \%$ concentration of $A$. officianlis were applied. A 20 seeds of $R$. sativus were placed in each Petri plates containing filter paper. To minimize the excess of evaporation petri plates were covered and rapped with parafilm. The petri plates were kept at the temperature of $30^{\circ} \mathrm{C}$ and were again moistened with $3 \mathrm{~mL}$ after one week. The data regarding emergence of the seeds were noted every day for 14 days. After the 14 days, harvest the germinated seedlings of $R$. sativus and observed the different parameters like shoot length, root length, fresh and dry weight. Fresh weight was recorded instantly after harvesting while the dry weight of seedling was observed after oven drying for two days at $60{ }^{\circ} \mathrm{C}$.

\section{Experimental site}

Laboratory experiments were conducted at weeds Science Laboratory, Department of Agronomy, University of Agriculture, Faisalabad to check the allelopathic effects of $A$. officinalis on radish (crop plant).

\section{Laboratory Experiment}

This study was carried out using water as extracting medium because allelochemicals are often water soluble and released into the environment through root exudation, leaching by dews and rains or decaying of plant tissue (Turk 
and Tawaha, 2003). Ten vigorous seeds of radish and wild pea were placed in Petri plates and $C$. verum and $A$. officinalis prepared aqueous solution were functionally applied at every specific petri dish purified water also cast-off like control treatment. After applying solution petri plate were wrapped with paper tape and placed at room temperature. Petri dishes would keep moisture by applying solution whenever needed. Percentage of germination, mean germination, root length, shoot length and fresh weight of root and shoot were taken afterward the $12^{\text {th }}$ day. Shoot length, root length was measured with measuring scale and fresh weight on weight machine. The diluted extracts of Althaea officinalis (0\%, 2.5\%, $5 \%, 10 \%, 20 \%, 40 \%, 80 \%)$ were applied separately on radish seed.

\section{Data collection}

\section{Mean emergence time of $R$. sativus} (MET).

Ellis and Reborts (1981) equation were used to examine the mean emergence time

Emergence index of $R$. sativus

$$
M E T=\frac{\sum(D n)}{\sum n}
$$

By using formula of association of the official seed analysis (1983) we record the emergence index

$$
G I=\frac{\text { No. of emerged seeds }}{\text { Days of first count }}+---+\frac{\text { No. of emerged seeds }}{\text { Days of final count }}
$$

\section{Emergence percentage of $R$. sativus}

No of emerged seeds were counted daily according to the method of the association of Official Seed Analysis (1990) and converted into emergence percentage by the following formula.

\section{Time taken to $\mathbf{5 0 \%}$ emergence of $\boldsymbol{R}$. sativus}

$$
\text { Emergence }(\%)=\frac{\text { No. of emerged seeds }}{\text { Total seeds }} \times 100
$$

The time to the $50 \%$ emergence $\left(E_{50}\right)$ was recorded by using the formula purposed by Coolbear et al. (1984)

$$
E \mathbf{5 0}=t i+\left[\frac{\frac{N}{2}-n i}{n j-n i}\right](t j-t i)
$$

\section{Growth attributes of $R$. sativus}

All seedlings from each petri plate were separated 14 days after emergence. After that both shoot length and root length were calculated by using meter rod from base level to top of the plants. Seedlings fresh weight was examined by separating seedlings from petri dish and measuring by using digital weight balance.

\section{Phenolic contents}

Phenolic contents were determined by using HPLC (Gradient, Reverse Phase made from shimadzu japan detector SPD10 Av Pump LC-10-AT). Made the (w/v) solution at 1.10 ratio $(10 \mathrm{~g}$ powdered of $A$. officanlis and $100 \mathrm{ml}$ methanol) Then wraped the beaker with aluminum foil and placed for 10 days. After 10 days the material was semidried. $5 \mathrm{mg}$ weight with electrical balance taken out for phenolic analysis. In $A$. officanlis Quercetin, Pcoumaric, ferulic acid, gallic acid and syringic acid were detected.

\section{Statistical analysis}

Statistics software (version, 8.1Statistix, Tallahassee, FL, USA) was used to analyze the collected data and least significant difference test (LSD) was used to compare the means of treatment at probability level of $5 \%$.

\section{Results and Discussions}
Allelopathic effect of Altheae officinalis on emergence of Raphanus sativus $\mathbf{L}$.
Time to $\mathbf{5 0} \%$ germination $\left(T_{50}\right)$ 
The aqueous extract of Althaea officinalis had significant effect on $\mathrm{T}_{50}$ of Raphanus sativus L. (Table 1 ). Maximum $\mathrm{T}_{50}(4.68)$ of radish seed was observed at $\mathrm{T}_{7}(80 \%)$ concentration. While minimum $\mathrm{T}_{50}$ (3.36) of radish seed was observed at $\mathrm{T}_{5}(20 \%) . \mathrm{T}_{7}(80 \%)$ concentration showed non-significant relationship with $\mathrm{T}_{1}(0 \%)$ concentration. $\mathrm{T}_{6}(40 \%)$ concentration showed non- significant relationship with $\mathrm{T}_{3} \quad(5 \%)$ concentration which was statistically at par with $\mathrm{T}_{4} \quad(10 \%)$ concentration. The $T_{50}$ of radish seed was significantly decreased by $22 \%$ at $T_{5}$ (20\%) concentration as compared to controlled $\mathrm{T}_{1}(0 \%)$. The time taken to $50 \%$ germination of radish seed was increased by $8 \%$ at $\mathrm{T}_{7}(80 \%)$ concentration as compared to controlled $\mathrm{T}_{1}(0 \%)$. Amongst all the treatments, $\mathrm{T}_{5}(20 \%)$ and $\mathrm{T}_{2}$ $(2.5 \%)$ showed reduced germination of seedling as compared to all other treatments.

Herro and Callaway (2003) reported that allelochemical had negative effects on crops in the ecosystem causing reduction in germination and growth of seedlings. Aqueous extract of certain plants induced mortality and inhibited germination of plants. According to Nadeem et al. (2020a) who reported that all the concentrations of $C$. tinctorius enhance the time to complete $50 \%$ emergence of $O$. punctata with $8 \%$ concentration Similar inhibitory effects of aqueous extracts.

\section{Germination index (GI)}

The effects of $A$. officinalis seeds extracts had significant effect on germination time of radish seeds described in Table (1). Maximum seed germination (6.00) was observed at control $\mathrm{T}_{1}(0 \%)$ concentration. The minimum germination (3.60) was observed at $\mathrm{T}_{5}(10 \%)$ concentration. $\mathrm{T}_{7}$ $(80 \%)$ concentration showed significant relationship with $\mathrm{T}_{4}(10 \%)$ concentration. $\mathrm{T}_{6}(40 \%)$ concentration showed nonsignificant relationship with $\mathrm{T}_{4}$ (10\%) concentration. Germination time of radish seed significantly decreased by $(3 \%)$ at $T_{7}$
(80\%) concertation as compared to control $\mathrm{T}_{1}(0 \%)$ concertation.

These results are parallel to the conclusion of Dongre and Singh (2007) and Yadav et al., (2007) described inhibitory effects posed by the water extract of different parts of Alternanthera species. Aqueous extract at high concentration were inhibitory. Nadeem et al. (2020b) reported that Water extracts of leaf of $C$. tinctorius at $8 \%$ concentration result in lowest $E$. cruss-galli emergence index.

\section{Mean germination time (MGT)}

The mean germination time of radish seed was significantly affected by the $A$. officinalis seed extract Table (1). Maximum MGT (9.05) of radish seed was observed at $\mathrm{T}_{7}(80 \%)$ concentration of extract. While minimum MGT (5.73) of radish seed was noted at $\mathrm{T}_{2}(2.5 \%)$ which was statistically at per with $\mathrm{T}_{5}(20 \%)$ concentrations. $\mathrm{T}_{7}(80 \%)$ concentration showed significant relationship with $T_{1}$ (0\%) concentration. $\mathrm{T}_{6} \quad(40 \%)$ concentration showed non-significant relationship with $\mathrm{T}_{1}(0 \%)$ concentration. The MGT of radish seed was statistically increased (14\%) at $\mathrm{T}_{7} \quad(80 \%)$ concentration of extract as compared to control $\mathrm{T}_{1}(0 \%)$ concentration. The MGT of radish seed was statistically decreased $(25 \%)$ at $\mathrm{T}_{5}(20 \%)$ concentration as compared to control $\mathrm{T}_{1}(0 \%)$ concentration.

Gao et al. (2009) reported that the germination inhibition is dependent on extract the concentration, it is might be to the entry of water solvable allelochemicals into the seed, which delays the growth and germination.

\section{Germination percentage (GP)}

The effect of $A$. officinalis seeds extract had significant effect on germination percentage of radish Table (1). Maximum germination percentage (100.0) of radish seed was observed at $\mathrm{T}_{1}$ $(0 \%)$ concentration of extract. While minimum germination percentage (85.0) of radish seed was noted at $\mathrm{T}_{7}(80 \%)$ concentrations. $\mathrm{T}_{7}(80 \%)$ concentration 
showed significant relationship with $\mathrm{T}_{1}$ (0\%) concentration. $T_{5} \quad(20 \%)$ concentration showed non-significant relationship with $\mathrm{T}_{4}(10 \%), \mathrm{T}_{3}(5 \%)$ and $\mathrm{T}_{2}$ $(2.5 \%)$ concentration of extract. The germination percentage of radish seed was statistically decreased $(15 \%)$ at $\mathrm{T}_{7}(80 \%)$ concentration of extract as compared to control $\mathrm{T}_{1}(0 \%)$ concentration.

From the findings of Zeng et al. (2008) it may be inferred that the allelopathic chemicals are distributed broadly among organs such as seeds, flowers, pollen, leaves, stems, and roots, however, just one or two of such organs inhibited germination and growth injury to certain food crops.

\section{Allelopathic effect of aqueous seed extract of Althea officinalis on seedling growth of Radish \\ Shoot length $(\mathbf{m m})$}

The effect of Althaea officinalis seeds aqueous extract on shoot length of Raphanus sativus $L$. was shown in Table (2). The aqueous extract of $A$. officinalis seeds had significant effect on shoot length of Raphanus sativus L. Maximum shoot length $(58.2 \mathrm{~mm})$ were observed at $\mathrm{T}_{7} \quad(80 \%)$ concentration which were statistically at par with that of $\mathrm{T}_{1}(0 \%)$ concentration. Minimum shoot length $(42.4 \mathrm{~mm})$ were observed at $\mathrm{T}_{2}(2.5 \%)$ concentration of extract. $\mathrm{T}_{7} \quad(80 \%)$ concentrations showed non-significant relationship with $\mathrm{T}_{6}(40 \%)$ which was statistically at par with $\mathrm{T}_{1} \quad(0 \%)$ concentration. $\mathrm{T}_{3} \quad(5 \%)$ concentration showed non-significant relationship with $\mathrm{T}_{4}(10 \%)$ and $\mathrm{T}_{5}(20 \%)$ concentrations. $\mathrm{T}_{2}$ (2.5\%) concentrations showed significant relationship with $T_{3}(5 \%)$ and $T_{1}(0 \%)$ concentration. The shoot length of radish increased $(3 \%)$ at $\mathrm{T}_{7}(80 \%)$ concentration as compared to control $\mathrm{T}_{1} \quad(0 \%)$ concentration while shoot length of radish decreased $(11 \%)$ at $\mathrm{T}_{5}(20 \%)$ as compared to control $\mathrm{T}_{1} \quad(0 \%)$ concentration. The results are supported by Rice (1984) analysis that difference in extract concentration might be shown different results, (both inhibitory and stimulating results in certain cases).

\section{Root length ( $\mathbf{m m})$}

The effect of $A$. officinalis (seeds) extract on root length of $R$. sativus $L$. were significant as describe in Table (2). Maximum root length $(52.0 \mathrm{~mm})$ of radish were observed at $\mathrm{T}_{1}(0 \%)$ concentration of the $A$. officinalis seeds extracts. Minimum root length $(25.9 \mathrm{~mm})$ of radish were observed at $\mathrm{T}_{7}(80 \%)$ concentrations of the extracts. The root length of radish was significantly decreased $(50 \%)$ at $\mathrm{T}_{7}(80 \%)$ concentrations as compared to control $\mathrm{T}_{1}$ $(0 \%)$ concentration. The root length of radish increased $(79 \%)$ at $\mathrm{T}_{4}(10 \%)$ concentration as compared to $\mathrm{T}_{7}(80 \%)$ concentration. $\mathrm{T}_{5}(20 \%)$ concentration showed non-statistically significant relationship with $\mathrm{T}_{6}(40 \%)$ concentration. $\mathrm{T}_{3}(5 \%)$ concentration showed nonsignificant relationship with $\mathrm{T}_{4}(10 \%) . \mathrm{T}_{7}$ $(80 \%)$ showed significant relationship with controlled $\mathrm{T}_{1}(0 \%) . \mathrm{T}_{2}(2.5 \%)$ showed significant relationship with control $\mathrm{T}_{1}$ ( $0 \%)$ concentration. $\mathrm{T}_{7} \quad(80 \%)$ concentration showed significant relationship with controlled $\mathrm{T}_{1}(0 \%)$ concentration. De Feo et al. (2003) examined the allelopathic effect of $A$. altissima liquid extracts on germination and successive root growth of radish (Raphanus sativus L.) and garden cress (Lepidium sativum L.) that have raised on petri plates comprising filter paper and saturated by liquid abstract of $A$. altissima. A. altissima extract suppressed the radical growth of Raphanus sativus (radish), and garden cress. Nadeem et al. (2020b) studied the effect of aqueous extracts of various parts of $C$. tinctorius on the root length of barnyard grass results revealed that minimum root length of barnyard grass was produced by produced by safflower leaves aqueous extract whereas, seedlings with lengthiest roots were noted by application of stem aqueous extracts of $C$. tinctorius.

\section{Shoot fresh weight $(\mathrm{mg})$}

The aqueous extract of $A$. officinalis seeds had nonsignificant effect 
on fresh weight of shoot of Raphanus sativus L. Table (2). Maximum fresh weight (90.0mg) of Raphanus sativus shoot was observed at $\mathrm{T}_{7} \quad(80 \%)$ concentration. Minimum fresh weight (50.0mg) of Raphanus sativus shoot was observed at $\mathrm{T}_{2}(2.5 \%)$ and $\mathrm{T}_{5}(20 \%)$ concentration. $\mathrm{T}_{7}(80 \%)$ concentration showed significant relationship with controlled $\mathrm{T}_{1}(0 \%)$ concentration. $\mathrm{T}_{2}$ $(2.5 \%)$ concentration showed nonsignificant relationship with $\mathrm{T}_{5}(20 \%)$ concentration while $\mathrm{T}_{3}(5 \%)$ concentration showed non-significant relationship with $\mathrm{T}_{4}(10 \%)$ concentration. The fresh weight of shoot was significantly increased (22\%) at $\mathrm{T}_{7}(80 \%)$ concentration as compared to control $\mathrm{T}_{1}(0 \%)$ while the fresh weight of shoot was significantly decreased $(27 \%)$ at $\mathrm{T}_{5}(20 \%)$ concentration as compared to control $\mathrm{T}_{1}(0 \%)$. The increase in fresh weight of radish seed may be due to the stimulatory allelochemicals in these extracts and shoot of radish showed more resistance at higher concentration of extract. While lower concentrations of extract were suitable to reduce the fresh weight of radish. That results are not corresponding to Shahida et al. (2002) that water extracts of plants and inflorescences at higher concentration suppressed the germination seedling growth and reduce the fresh and dried mass of barley wheat, radish and pea. The results are supported by Rice (1984) analysis that difference in extract concentration might be shown different results, (both inhibitory and stimulating results).

\section{Root fresh weight (mg)}

The effect of aqueous extract of Althaea officinalis seeds were significant on fresh weight of radish root as described in Table (2). The fresh weight of radish root was mainly reduced as concentration of extract increase. Maximum fresh weight (26.3mg) of root was observed $T_{1}(0 \%)$ concentration. While minimum fresh weight $(13.3 \mathrm{mg})$ of root was observed at $\mathrm{T}_{7}(80 \%)$ concentration of the extract. $\mathrm{T}_{7}$ $(80 \%)$ concentration showed nonsignificant relationship with $\mathrm{T}_{5}(20 \%)$ concentration. $\mathrm{T}_{2}(2.5 \%)$ concentration showed non-significant relationship with $\mathrm{T}_{3} \quad(5 \%)$ concentration. $\mathrm{T}_{4} \quad(10 \%)$ concentration showed significant relationship with $\mathrm{T}_{7}(80 \%)$ concentration. The fresh weight of radish was significantly decreased $(49 \%)$ at $\mathrm{T}_{7}(80 \%)$ at par similar with $\mathrm{T}_{5}(20 \%)$ concentration as compared to control $\mathrm{T}_{1} \quad(0 \%)$ concentration. The fresh weight of radish root was significantly reduced at different concentration of extract as compared to controlled treatment. These results were supported with the finding of Daniel (1999) and Uddin et al. (2000) that mass of root and shoot development were significantly reduced as increase the concentration of aqueous extract. These findings also in accordance with Sisodia and Siddiqui (2008) who stated that the inhibition effect was found to increase with increasing concentration at different aqueous extracts.

\section{Phenolic compounds and their concentration in $C$. verum and $A$. officinalis}

Phenolic compounds and their concentration in $A$. officinalis were presented in Table 3 . In $A$. officinalis minimum Syringic acid $(0.60 \%)$ and maximum Quercetion (12.3\%) compound was found.

\section{Conclusion:}

The results of experiment directed that aqueous extract of $A$. officinalis showed inhibitory effect on radish germination and seedling growth at higher concentration $(80 \%)$ and growth regulatory effect at lower concentration So, aqueous extract of $A$. officinalis can be use as potential bioherbicide to control weed at $80 \%$ concentration and growth regulator at lower concentration. 
Table 1: Allelopathic effect of A. officinalis on emergence of seeds of $R$. sativus

\begin{tabular}{|l|l|l|l|l|}
\hline $\begin{array}{l}\text { Concentration } \\
(\%)\end{array}$ & $\begin{array}{l}\text { Time to 50\% } \\
\text { germination }\end{array}$ & $\begin{array}{l}\text { Germination } \\
\text { Index }\end{array}$ & $\begin{array}{l}\text { Mean } \\
\text { germination } \\
\text { Time }\end{array}$ & $\begin{array}{l}\text { Germination } \\
\%\end{array}$ \\
\hline $0 \%$ & $4.32 \mathrm{ab}$ & $5.21 \mathrm{bc}$ & $7.93 \mathrm{bc}$ & $91.6 \mathrm{ab}$ \\
\hline $2.5 \%$ & $3.54 \mathrm{c}$ & $3.87 \mathrm{~d}$ & $7.43 \mathrm{~cd}$ & $93.3 \mathrm{ab}$ \\
\hline $5 \%$ & $4.01 \mathrm{~b}$ & $4.87 \mathrm{c}$ & $7.12 \mathrm{~d}$ & $93.3 \mathrm{ab}$ \\
\hline $10 \%$ & $3.36 \mathrm{c}$ & $6.00 \mathrm{a}$ & $5.73 \mathrm{e}$ & $100.0 \mathrm{a}$ \\
\hline $20 \%$ & $4.25 \mathrm{~b}$ & $5.81 \mathrm{ab}$ & $5.93 \mathrm{e}$ & $93.3 \mathrm{ab}$ \\
\hline $40 \%$ & $4.25 \mathrm{~b}$ & $5.22 \mathrm{bc}$ & $8.13 \mathrm{~b}$ & $86.6 \mathrm{~b}$ \\
\hline $80 \%$ & $4.68 \mathrm{a}$ & $3.60 \mathrm{~d}$ & $9.05 \mathrm{a}$ & $85.0 \mathrm{~b}$ \\
\hline LSD: & $\mathbf{0 . 3 8 2 6}$ & $\mathbf{0 . 6 7 5 3}$ & $\mathbf{0 . 6 7 6 4}$ & $\mathbf{8 . 5 4 5 0}$ \\
\hline
\end{tabular}

Table 2: Allelopathic effect of $A$. officinalis on seedling growth of seeds of $R$. sativus

\begin{tabular}{|l|l|l|l|l|}
\hline $\begin{array}{l}\text { Concentration } \\
(\%)\end{array}$ & $\begin{array}{l}\text { Shoot length } \\
(\mathbf{c m})\end{array}$ & $\begin{array}{l}\text { Root length } \\
\mathbf{( c m )}\end{array}$ & $\begin{array}{l}\text { Shoot fresh } \\
\text { weight (g) }\end{array}$ & $\begin{array}{l}\text { Root fresh } \\
\text { weight (g) }\end{array}$ \\
\hline $0 \%$ & $56.2 \mathrm{a}$ & $46.4 \mathrm{~b}$ & $73.3 \mathrm{c}$ & $20.0 \mathrm{c}$ \\
\hline $2.5 \%$ & $46.8 \mathrm{~b}$ & $37.3 \mathrm{c}$ & $50.0 \mathrm{e}$ & $23.3 \mathrm{~b}$ \\
\hline $5 \%$ & $49.7 \mathrm{~b}$ & $43.9 \mathrm{~b}$ & $60.0 \mathrm{~d}$ & $23.3 \mathrm{~b}$ \\
\hline $10 \%$ & $58.2 \mathrm{a}$ & $52.0 \mathrm{a}$ & $90.0 \mathrm{a}$ & $26.3 \mathrm{a}$ \\
\hline $20 \%$ & $56.6 \mathrm{a}$ & $31.0 \mathrm{~d}$ & $83.3 \mathrm{~b}$ & $16.6 \mathrm{~d}$ \\
\hline $40 \%$ & $50.2 \mathrm{~b}$ & $31.6 \mathrm{~d}$ & $63.3 \mathrm{~d}$ & $13.3 \mathrm{e}$ \\
\hline $80 \%$ & $42.4 \mathrm{c}$ & $25.9 \mathrm{e}$ & $53.3 \mathrm{e}$ & $13.3 \mathrm{e}$ \\
\hline LSD: & $\mathbf{3 . 8 6 2 7}$ & $\mathbf{3 . 4 4 3 1}$ & $\mathbf{4 . 8 3 3 8}$ & $\mathbf{2 . 9 6 0 1}$ \\
\hline
\end{tabular}

Table 3: Phenolic compounds and their concentration in A. officinalis

\begin{tabular}{|l|l|}
\hline Phenolic compounds & Concentration (\%) \\
\hline Syringic acid & 0.60 \\
\hline p-crumeic & 0.94 \\
\hline Ferulic acid & 7.48 \\
\hline Quercetion & 12.3 \\
\hline Gallic acid & 4.69 \\
\hline
\end{tabular}




\section{References}

Anwar, S., W. A. Shah, M. Shafi, J. Bakht and M. A. Khan. 2003. Efficiency of sorgaab (sorgaab) and herbicide for weed control in wheat (Triticum aestivum) crop. Pak. J. Weed Sci. Res. 9: 161-170.

Association of Official Seed Analysis 1990. Rules for testing seeds. J. Seed Technol. 12: 1-112.

Cheema Z. A., I. Jaffe and A. Khaliq. 2003. Reducing isoproturon dose in combination with sorgaab for weed control in wheat. Pak. J. Weed. Sci. Res. 9: 153-160.

Cheema, Z and A. Khaliq 2000. Use of sorghum allelopathic properties to control weeds in irrigated wheat in a semi-arid region of Punjab. Agric. Ecosyst. Environ. 79: 105-112.

Cheema, Z. A., A. Rakha and A. Khaliq 2000a. Use of sorgaab and sorghum mulch for weed management in mungbean. Pak. J. Agric. Sci. 37: 140-144.

Cheema, Z. A., M. Asim and A. Khaliq 2000b. Sorghum allelopathy for weed control in cotton (Gossypium arboreum L.) Int. J. Agric. Biol. 2: 37-41.

Cheema, Z. A., M. Farooq and A. Khaliq. 2012. Application of allelopathy in crop production success story from Pakistan. In Allelopathy. Springer, Berlin, Heidelberg. Current Trends and Future Applications. p: 113-143.

Coolbear P., A. Francis and D. Grierson. 1984. The effect of low temperature pre-sowing treatment on the germination performance and membrane integrity of artificially aged tomato seeds. J. Exp. Bot. 35: 1609- 1617.

Daniel, W. G. 1999. Historical review and current models of forest succession and interference. CRC Press LLC: 237-251.

De Feo, V., L. De Martino, E. Quaranta and C. Pizza. 2003. Isolation of phytotoxic compounds from Tree-ofHeaven (Ailanthus altissima). J. Agric. Food Chem. 51: 1177-1180.
Dongre, P. N. and A. K. Singh. 2007. Inhibition effects of weeds on growth of wheat seedlings. Allelopathy $\mathrm{J}$. 20: 387-394.

Einhellig, F. A. and I. F. Souza. 1992. Phytotoxicity of sorgoleone formed in grain Sorghum root exudates. J. Chem. Ecol. $18: 1-11$.

Einhellig, F. A. and I. F. Souza. 1992. Phytotoxicity of sorgoleone found in grain sorghum root exudates. J. Chem. Ecol. 18:1-11.

Ellis, R.A. and E.H. Roberts. 1981. The quantification of aging and survival in orthodox seeds. Seed Sci. Technol. 9: 373-409.

Gao, X., M. Li, Z. Gao and C. Li. 2009. Allelopathic effects of Hemistepta lyrata on the germination and growth of wheat, sorghum, cucumber, rape, and radish seeds. Weed Bio. Manag. 9: 243- 249.

Golisz, A., B. Lata, S. W. Gawronski and Y. Fujii. 2007. Specific and total activities of the allelochemicals identified in buckwheat. Weed Bio. Manag. 7(3): 164-171.

Hazrati, H., M. J. Saharkhiz, M. Niakousari and M. Moein. 2017. Natural herbicide activity of Satureja hortensis L. Essential oil nanoemulsion on the seed germination and morphophysiological features of two important weed species. Ecotoxicol. Environ. Saf. 142: 423-430.

Herro, J.L. and R.M. Callaway. 2003. Allelopathy and exotic plant invasion. Plant and Soil. 256: 29-39.

Iqbal, J. and Z. A. Cheema. 2008. Purple nutsedge (Cyperus rotundus L.) management in cotton with combined application of sorgaab and s-metolachlor. Pak. J. Bot. 40(6): 2383-2391.

Jamil, M., Z. A. Cheema, M. N. Mushtaq, M. Farooq and M. A. Cheema. 2009. Alternative control of wild oat and canary grass in wheat fields by allelopathic plant water extracts. Agron. Sustain Dev. 29: 475-482. 
King, S. R. and R. Ambika. 2002. Allelopathic plants. 5. Chromolaen odorata L. Allelopath. J. 9: 35-41.

KIng, S., and R. A. Ambika. (2002). 5. Chromolaena odorata (L.). Allelo. J. Philad. 9(1): 35-41.

Kubeczka, K. H. 2002. Essential Oils Analysis by Capillary Gas Chromatography and Carbon13 NMR Spectroscopy. Hoboken, NJ: John Wiley and sons.

Mhaskar, K. S., E. Blatter, E and J. F. Caius. 2000. Kirtikar and Basu's illustrated Indian J. Plant. 2: 405407.

Murrell, C., E. Gerber. C. Krebs. M. Parepa. U. Schaffner and O. Bossdorf. 2011. Invasive knotweed affects native plants through allelopathy. Ameri. J. Bot. 98(1): 38-43.

Nadeem, M. A., B. A. Khan, S. Afzal, A. Aziz, R. Maqbool, M. M. Amin, A. Aziz, A. Ali, M. Adnan and Durrishahwar. 2020b. Allelopathic Effects of aqueous extracts of Carthamus tinctorius L. on emergence and seedling growth of Echinochloa crus-galli L. Pak. J. Weed Sci. Res. 26(3): 365-379.

Nadeem, M. A., B. A. Khan, S. Afzal, M. A. Khan, T. Abbas, M. M. Javaid, M. M. Amin, N. Farooq and A. Aziz. 2020a. Effect of aqueous extract of Carthamus tinctorius L. on germination and initial seedling growth of Oryza punctata L. Pak. J. Weed Sci. Res. 26(3): 331-342.

National Institute of Science Communication and Information Resources. 2003. The wealth of India: Raw materials. 1: 207-208.

Putnam, A. R. and W. B. Duke. 1974. Biological suppression of weeds: Evidence for allelopathy in accessions of 440 cucumber. Science. 185: 370-372.

Rice, A., J. Johnson-Maynard, D. Thill and M. Morra. 2007. Vegetable crop emergence and weed control following amendment with different brassicaceae seed meals. Renew. Agr. Food Syst. 9: 475-482
Rice, E. L. 1984. Manipulated Ecosystems: Role of Allelopathy in Agriculture, In: Allelopathy, 2nd Ed., Academic Press, Orlando, pp:8-73.

Shahida, K., T. Ahmad and R.A. Shah. 2002. Use of allelopathy in Agriculture. In: Asian J. Plant Sci. 1: 292-297.

Siddiqui, S., K. K. Shaukat and M. K. Meghvanshi. 2009. Allelopathic effect of aqueous extract of Acacia niloticaon seed germination and radicle length of Triticum aestivum L. Ind. J. Applied and Pure Bio. 24: 217-220.

Sisodia, S. and M. B. Siddiqui. 2008. Allelopathic effect of Lantana camara on Bidens Pilosa. Vegtos. 20: 29-32.

Sodaeizadeh, H., M. Rafieiolhossaini and P. van Damme. 2010. Herbicidal activity of a medicinal plant, Peganum harmala L., and decomposition dynamics of its phytotoxins in the soil. Indus. Crops Prod. 31(2): 385-394.

Turk, M. A. and A. M. Tawaha. 2003. Allelopathic effect of black mustard (Brassica nigra L.) on germination and growth of wild oat (Avena fatua L.), Crop Prot. 22: 673-677.

Uddin, M. B., R. Ahmed and M. K. Hossain. 2000. Allelopathic potential of water extracts of Leucaena leucocephala leaf on some agricultural crops in Bangladesh. The Chitta. Uni. J. Sci. 24: 121-127.

Yadav, P. K., A. H. Khan and A. S. Yadav. 2007. Effect of herbicides on biochemical and growth parameters of chickpea (Cicer arietinum L.). Ind. J. Agric. Sci. 77: 542-543.

Zeng, R. S., A. U. Mallik and S. M. Lou. 2008. Allelopathy in Sustainable Agriculture and Forestry, SpringerVerlag, Germany. p:412. 